\title{
IMPLEMENTATION OF M-FLEX BASED MOODLE IN PANCASILA COURSE: AN INITIAL EVALUATION ON STUDENT'S VIEW
}

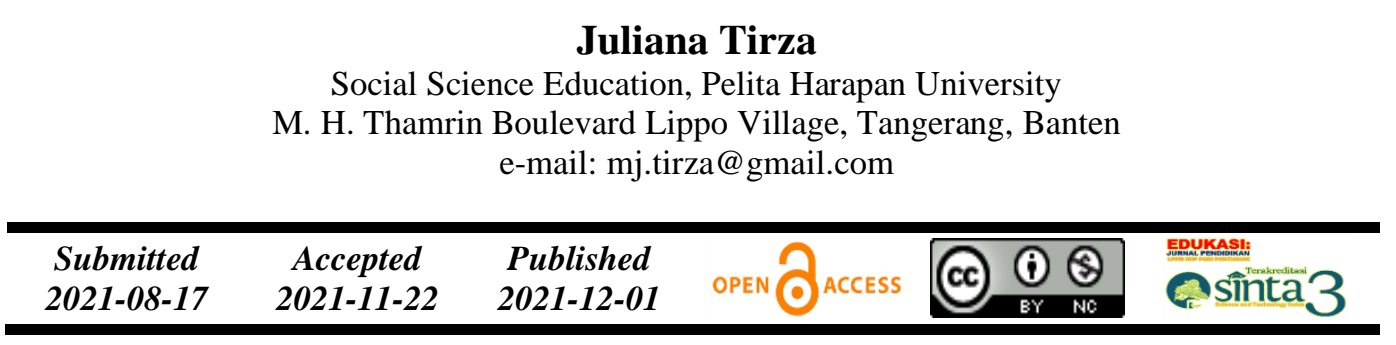

\begin{abstract}
M-Flex is the approach used by utilizing various interesting and quality online learning maneuvers. Moodle-based M-Flex learning specifically in Pancasila learning is the focus of this research. The research aimed to see students' initial responses to Moodle-based M-Flex and monitor any benefits and security felt by users. The approach used is qualitative, with interviews as research instruments. The research respondents were 9 students. Analysis procedures used descriptive qualitative methods. In conclusion, the application of M-Flex based on Moodle still faces several challenges related to students' internet connections, the lack of training in using Moodle for students in Pancasila classes, and the assessment design which is still less varied. M-Flex based on Moodle, on the other hand, shows an advantage because it is supported by Moodle features that continue to develop.
\end{abstract}

Keywords: online learning; Moodle; learning strategy.

\begin{abstract}
Abstrak
M-Flex adalah pendekatan yang digunakan dengan memanfaatkan berbagai manuver pembelajaran dalam jaringan yang menarik dan berkualitas. Pembelajaran M-Flex berbasis Moodle khusus dalam pembelajaran Pancasila dijadikan fokus dalam penelitian. Tujuan penelitian untuk melihat respons awal mahasiswa terhadap M-Flex berbasis Moodle dan memantau setiap manfaat serta keamanan yang dirasakan oleh penggunanya. Pendekatan yang digunakan adalah kualitatif dengan wawancara sebagai instrumen penelitian. Responden penelitian sebanyak 9 mahasiswa. Prosedur analisis menggunakan metode deskriptif kualitatif. Kesimpulannya penerapan M-Flex berbasis moodle masih menghadapi beberapa tantangan terkait koneksi internet mahasiswa, kurangnya pelatihan penggunaan moodle bagi mahasiswa dalam kelas Pancasila dan rancangan asesmen yang masih kurang variatif. M-Flex berbasis Moodle di sisi lain memperlihatkan keuntungan karena ditunjang fitur moodle yang terus berkembang.
\end{abstract}

Kata Kunci: pembelajaran online; Moodle; strategi pembelajaran.

\section{INTRODUCTION}

The development of information technology that occurs in this country is increasingly advanced, along with the development of the global market era. The development of information technology is widely used to improve the support of human life activities. In the realm of education, the presence of information 
technology is one of the opportunities for designing educational programs. The use of the internet in the framework of web-based learning media is a form of elearning that is currently being popularly developed by various educational institutions. Internet technology, which is interactive, flexible, and not limited to space and time, is expected to be one of the superior learning media (Riyanto, 2011). E-learning is a technology-based learning tool used as learning support in today's digital era. Four benefits can be obtained from using e-learning; personal involvement in learning, reduce expenses, accessible reach, and capacity to be efficient (Riyanto, 2011).

The development of information and communication technology is very significant. The progression of information and communication technologies has brought about significant changes in people's lives. Society has become informed by the efficiency of access to data in the industrial era 4.0, including education. Education commits to developing technology and plays a vital role by giving commencement to learning applications, Moodle. Moodle is a learning application that can be obtained using an internet proxy. The man behind this LMS is Martin Douglamas, he used a content management system for education and found it difficult to obtain, it even doesn't help him to reach the learning objective. He finally decided to continue his study in technology and education then created something even better, which is Moodle (Dvorak, 2011). Considering the pandemic hit the world, since the announcement of the first COVID-19 case in Indonesia, all education policies in Indonesia, even around the world, have migrated from face-to-face learning to online learning. A revolution that has never been thought of before and has made many educational institutions begin looking for online learning designs that are following the features of children and schools in their regions (Giorgi, 2020).

Unpreparedness is still following this mass change. There are still many areas in this country that do not yet provide reliable internet connections. The baby boomers generation still dominates among teachers in this country (Bowo, 2016). They do not understand how to use the internet or learning platforms. Another major problem in online education is that a large amount of learning is 
Edukasi: Jurnal Pendidikan, Volume 19 Nomor 2 Tahun 2021

Implementation of M-Flex Based Moodle in Pancasila Course......

Juliana Tirza

Halaman 201-215

passive for most students (Bork, 2012). Internet quota costs are incredibly expensive, and they are undergoing financial difficulties simultaneously due to efficiency everywhere during the pandemic (Efriana, 2020). Various problems occur systemically, but educational institutions, especially universities, must immediately improve themselves so that they are not left behind and can proceed to provide quality education even with a different method and a policy that has never been experienced before.

Higher education institutions require to think about a practical curriculum, following social distancing provisions, and still promote the germination of learning impulse among scholars. Motivation to learn and quality is a massive problem in this season (Mustafa, 2020). Minimal social interaction, distressing circumstances due to the spread of the virus, mental health states due to excessive anxiety, and the various effects of a pandemic can diminish student motivation. The congestion felt due to the social environment and limited socialization during the pandemic also reads the adverse effects on student learning. So that universities need a curriculum that can be applied online and can manage burnout and engage the quality of learning expected by students and all stakeholders.

Moodle, as a learning application now, has various advantages and disadvantages. The advantages of Moodle can generate effective learning, able to realize distance learning, can be accessed for free, helping to ease the task of teachers. On the other hand, Moodle also has a weakness: it requires an internet connection to be accessible, so it is not suitable for areas with weak internet connections. Based on statistics on its website, Moodle has been used in 230 countries in the world (Calle-Urgiléz, 2018), countries in Europe and America dominate its use.

In Asia, there are only two countries that dominate Moodle's use, particularly Indonesia and India. Indonesia has only 2,434 registered official sites on it. According to this data, Indonesia is just a small number compared to the first Moodle user country globally, namely the United States, with around 10.000 registered sites. Widely used in Indonesia's education sector, Moodle certainly has a lot of benefits and positive impacts on scholars, teachers, and lecturers. There 
are not many procedures in access to its use, so Moodle is practical and useful for anyone (teachers and students). Based on the facts above, the authors explain Moodle and its use in facilitating the teaching and learning process in education.

Using reliable sources and data, the authors describe some of the arguments and responses from the author. The formulation of the problem to find the answer in this study is performing the M-Flex approach based on Moodle for one month of implementation. Is there any feedback that can be seen from students in subject Pancasila. The advantage of this research is that it can accommodate the results of an initial evaluation in applying the M-flex learning strategy in the Pancasila course for lecturers in the investment that the lecturers can identify the strengths and inclinations of this curriculum early on during this COVID-19 pandemic. Furthermore, theoretically, this research is also valuable in improving and adding to scientific horizons related to the construction of the Moodle-based Pancasila curriculum to be a reference or source for conducting further e-learning curriculum development research during the COVID-19 pandemic.

\section{METHOD}

Research on the utilization of M-Flex based on Moodle uses a qualitative descriptive approach. Qualitative research deals with ideas, perceptions, opinions, and beliefs of the person being studied, all of which cannot be measured by numbers. In this research, the theory used in research is not forced to obtain a complete picture of something according to the human perspective that has been studied the interviewees in this research used as a data resource, particularly determining informants based on specific criteria or considerations. The selection of informants in this research based on the first criteria is that informant obligation attended Pancasila classes, first-year students, and have Moodle access. The research interview was conducted without coercion, with students having to declare their willingness to become informants.

Processing technique data collected is processed, and data processing is done by triangulation, reduction, data presentation, and concluding. Triangulation is a data validity checking procedure that uses something other than the data compared 
Edukasi: Jurnal Pendidikan, Volume 19 Nomor 2 Tahun 2021

Implementation of M-Flex Based Moodle in Pancasila Course......

Juliana Tirza

Halaman 201-215

to the data. There are three triangulation types, specific triangulation with sources, triangulation with techniques, and triangulation of time. In this research, the researcher used triangulation using sources, mainly by checking the data from various sources. In this research to test the credibility of the data on M-Flex application, the data obtained were tested on students who were the subjects of the study and adjusted to existing theories.

After triangulating, the researcher made a reduction, namely summarizing, selecting main things, and focusing on important things. That way, the reduced data provides a clearer picture. In this study, researchers focused on the application of M-Flex based on Moodle in the Pancasila class. After reducing the data, the next step is to present the data. The researcher exhibited the data by writing the results in descriptive narrative text. Data are presented by grouping according to each sub. After presenting the data, the next step is concluding. After describing the various data that had been obtained, the researcher made a conclusion which was the result of the research.

Researchers conducted information analysis procedures using descriptive qualitative methods. The data acquired through interviews in this study were analyzed using qualitative descriptive analysis, particularly by thoroughly explaining any informants' information. Qualitative research must have reliability so that it can be justified. Reliability is the benefit of obtaining the intention to chlorinate multiple problems or the trustworthiness of the study data results. Efforts to maintain credibility in research are through the following steps. Extending observations, increasing persistence, making observations more carefully, triangulating checking data as a source in various ways and various times, and using reference materials.

This research looks at how the M-Flex is implemented based on moodle in one of Indonesia's private university in Tangerang. Its name was not mentioned on the initiative of the researcher to ensure the confidentiality of research subject information. The researcher took 3 sample classes with 9 students from social education major in this university. Each informant filled in the answers to the written interview questions and the researcher made it sure through Zoom 
interview with three questions, if you were asked to explain M-Flex based on Moodle to people outside this institution, what answer would you give? How is your personal learning experience after participating in 4 meetings with M-Flex based on Moodle? Are there any obstacles that you feel? The informants explained their respective answers. Researchers processed the data obtained from informants by transcribing the text, reducing, analyzing, and presenting data.

Provisional estimates from researchers, students have a good impression of M-Flex based on Moodle. Students feel that their online classes are more meaningful than the online classes they experienced when they were in the twelfth grade of high school. This happened because M-Flex used Moodle as its implementation platform. Moodle allows interaction to occur and allows feedback to occur. The gamification feature makes children even more happy and excited about taking online classes without neglecting the essence of the Pancasila course as the basis of the state. Another allegation is that students still find problems in using Moodle. Students who take the Pancasila class are first-year students who are not familiar with Moodle, so they have the opportunity to raise many questions regarding the platform.

\section{RESULT AND DISCUSSIONS}

The use of e-learning for online distance learning has often been used, as for some of the advantages of using e-learning according to Bates and Wulf (Munir, 2012). Particularly increasing enhance interactivity during this pandemic. Learners who are separate from other learners and separate from the teacher will observe more unobstructed state ideas or ask questions because no other student is physically perceiving him/herself. This conducive state of learning activities and feelings of learners will be able to encourage learners to increase the level of interaction in learning activities so that learning outcomes are more optimal. Second, promote learning interactions from anywhere and anytime (time and place flexibility). Learners can carry learning resources at any time according to their time availability and wherever they are because learning resources have been 
Edukasi: Jurnal Pendidikan, Volume 19 Nomor 2 Tahun 2021

Implementation of M-Flex Based Moodle in Pancasila Course......

Juliana Tirza

Halaman 201-215

packaged electronically and available to be accessed by learners through online learning.

Third, have a broader reach (potential to reach a global audience). Online distance learning is flexible in terms of time and place, presenting the number of learners that can be reached by learning activities through online learning is increasing and broadly exposed. Space, area, and time are no longer obstacles. Anyone, anywhere, and anytime, can learn through their interaction with learning resources that have been packaged electronically and are ready to be accessed through online learning. Make it easy to update and store learning supplies (easy updating of content and archivable capabilities). The facilities available in online elearning technology and various software that continue to develop also help facilitate the development of electronic learning materials, both based on feedback from learners and teacher assessments.

There are various characteristics of e-learning media, which are the properties of this media connected to other media samples. As for general, elearning media have the following characteristics, Non-linearity - Users are free to obtain objects or materials in this e-learning. Self-Managing - Users can control the learning process themselves by following the structure that has been created. Feedback-Interactivity-learning can be done interactively, and feedback is provided on the learning process. Multimedia-Learners Style E-learning contributes to multimedia tools. Students can understand the convenience of using multimedia more clearly and clearly according to the type of student. Fifth, Just in Time - E-learning provides users whenever they need to solve problems or want to increase their knowledge and skills. Sixth, Dynamic Updating - Can update the material's contents automatically on the newest modifications. Easy Approachability - Easy to access from anywhere and anytime by the user. Collaborative Learning - Enables interaction with each other, directly communicating at the same time, or communicating at different times (Meylani et al., 2015). Users can communicate with content creators, other students, and visitors. 
Moodle stands for Modular Object-Oriented Dynamic Learning Environment. This Moodle application was founded in 2002 by Martin Dougiamas, an educator and computer scientist based in Australia (Dent, 2018). Moodle exists as a derivative form of the e-learning program. Moodle as a webbased e-learning program includes concepts and teaching and learning methods. Moodle can be accessed via an internet proxy. Moodle application has been widely used by the world community, especially in the world of education, including universities and schools (Rohana, 2019). The following is a table that describes the Moodle function.

The benefits of Moodle as a learning application have various benefits for several parties, both teachers and students. This web-based application was created to facilitate the learning process. Even more so in the distance learning process (Chatib et al., 2019). The advantages include making it easier for students and students to collect assignments. Can be used as a reminder of an assignment that is entering the collection grace period. Avoid plagiarism because there is Turnitin which can be accessed through Moodle. A powerful feature for the distance learning process. Not wasting paper because the task collection system can be done online. Make it easy for students or students to see the schedule of lessons or courses being taken. The drawbacks include high funding. Requires experts to be able to operate the system. Requires an internet connection to perform its function.

Moodle has various facilities that can be useful to support learning activities. The facilities available at Moodle include assignments, chat, forums, quizzes, and surveys. The explanation for each facility is as follows, assignments are used to provide assignments to students online (Amiroh, 2012). Students can access assignment materials and submit assignments by sending files of their work results. Chat is used by teachers and students to interact with each other online by means of text dialogue (online conversation). The forum is an online discussion forum between teachers and students that discusses topics related to learning materials. Quizzes are used by teachers to do online test exams. The survey is used to conduct polls. 
Edukasi: Jurnal Pendidikan, Volume 19 Nomor 2 Tahun 2021

Implementation of M-Flex Based Moodle in Pancasila Course......

Juliana Tirza

Halaman 201-215

Higher education institutions require to implement meaningful learning, even amid a pandemic and distance learning programs. Significant learning is learning that is centred on the process of discovering how to learn itself. Moreover, some constituent aspects include basic knowledge, learning methods, attention, human dimensions, integration, and utilization. The M-Flex curriculum stands for MultiFlexible Learning (Fink, 2013). In meaningful learning, it is always accompanied by several significant changes that can be felt by students. In the process, always inquiring about what kind of learning do the lecturers want students to learn? How do lecturers design their lectures? These two questions are essential and necessary when it proceeds to design meaningful learning.

When we want to design meaningful learning, we need to pay attention to the critical components in designing courses, particularly the teaching and learning method, learning objectives and feedback, evaluation tools and ensure that these three components are integrated. Another thing that the learning design process needs to consider is the circumstances factor. This process requires paying attention to the university's vision and mission, the provision of students, the circumstance of the lecturers, the availability of technology, the characters of courses, and the curriculum. In this study, the authors scrutinized the scope of the Pancasila course. Steps that we can use are, giving more attention to situational factors, after that we can determine the goal of learning, create feedback, develop activities, let students involve to get more expansive learning goals (Fashant, 2019).

In the application of M-Flex, students and lecturers conduct face-to-face sessions using video conferencing. This makes it more attractive and brings positive responses from students. Video conferencing can enhance learning activities and facilitate collaborative discussions (Candarli \& Yuksel, 2012). In video conferencing, active interaction can occur and student responses can be measured quickly, such as asking sudden questions to make sure they are focused and listening to the conversation that is happening. Conduct group presentations by providing opportunities for students to share their ideas. 
Multi flexible learning or M-Flex applied in this university implies practicing or maximizing the university's support to promote effective teaching strategies when interacting with students. The resources in the subject include material resources, human resources, and technological resources. This approach emphasizes flexibility in the instruction and learning process, as in various surveys conveyed on students in this university before performing the M-Flex. Many students demand an aspect of flexibility when studying online, especially during a pandemic. This approach also prioritizes the health and safety of each user. Considering the beginning of the pandemic, several have sought health factors and security, including data security for internet platform users, therefore presenting this approach is a solution to this concern.

The goal of m-flex is to achieve a neutral factor in terms of time. As discussed earlier, the flexibility of time is the greatest hope of students. Flexible here means students can have flexible time and effectively engage with the material in online learning (Kohkoc, 2019). Another goal is to achieve learning goals and graduate competencies that are derivatives of the university's vision and mission. Another goal is to realize active learning strategies that occur with students during synchronous sessions between lecturers and students. M-flex does not aim for lecturers to always apply lectures during class, but to apply various teaching methods that hone students' soft skills in communicating, creating and giving opinions, and facilitating the presence of new ideas in every study room, especially in this paper the Pancasila course.

Now, what kind of active learning strategy has been applied by lecturers in the Pancasila subject when initially implementing m-flex? Some of the things that appear in Pancasila's learning are analogies. Namely presenting one or more concepts, then students see the similarities of these concepts. In Pancasila lectures, case studies are also applied to various topics in this course. This is the learning strategy that comes up most often. Moodle facilitates the presence of this strategy by providing a forum feature. There are case questions such as in Figure 1. 


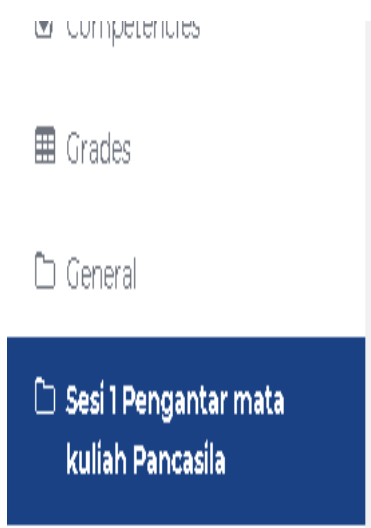

\section{Q. Forum Diskusil:Mendiskusikan ttg mengapa mata kuliah inisangat $\quad$ v} penting bagigenerasi muda.

menurut Anda, apakah mata kullah in penting bagi generasi muda Indonesia?? Apakah mata kullah ini penting bagi|Anda yang sedang

\section{menekuni bidang yang Anda tekuni saat in?? Mengapa demikian 200} kata max, no plagiarism allowed)

\section{Figure 1 Feature in Moodle that can Promote an Active Learning}

This forum feature allows lecturers to generate questions based on actual cases in society regarding Pancasila and ask students to appoint them directly during class and share their ideas. In its utilization, students are very enthusiastic and able to design logical explanations and question the meaning of their peers' answers. Students give positive responses to active teaching strategies in the form of case studies. A template in Moodle that allows lecturers to enter a PDF document containing journal articles that can be discussed during synchronous class sessions. Moodle allows lecturers to put some journals related to Pancasila topics and students give positive responses. The positive response of students can be seen from the analytics feature in Moodle. This feature functions as an indicator of the number of participants accessing the document in Moodle.

How to use M-Flex to accomplish significant learning related to flexibility and practical learning? The end goal is the long-term transformation of students (Brooks, 2019). Three essential things related to learning that lead to long-term change are information and ideas, which can evolve from primary and secondary knowledge. Students can obtain this information and ideas online as well as outside the classroom. Lecturers can perform or apply the flexibility aspect of this component. Information regarding Pancasila as the basis of the state, Pancasila in history, Pancasila as a philosophical system, Pancasila as the state ideology, Pancasila as an ethical system, these materials are rich in information. Students can access all of this material both inside and outside the classroom outside the lecture schedule. The related component is experience. Students experience or feel for themselves the learning that is happening, in this case, Pancasila. 
Students make observations based on the information they have received. In learning Pancasila for Pancasila's topic as the basis of the state, students observe its application in the life of the nation and state according to the concepts they have learned in the information and idea stages. Students see the government's success or failure to provide an example of the application of Pancasila as the basis of the state in legal products. The student response was excellent. It was felt when participants who participated in the discussion were always interactive and willing to report their observations. The application of this learning experience aims to add or enrich the learning experience of students.

The concluding component of the active learning design in the M-Flex learning approach is reflection. Students in the Pancasila class reflect on what they have learned. Usually, the lecturer will ask 3-5 students in the class to give their reflections on the things that have been learned. Students are also biased in expressing how they feel about attending class, either individually or with their peers. The results of the evaluation of this component in the Pancasila class show the willingness of students to provide their reflections regarding what and how they feel about learning. So that students do not feel uncomfortable sharing, students are divided into small discussion rooms where they are comfortable sharing their thoughts and ideas.

M-Flex, which utilizes the Moodle platform, looks more organized and controlled well by its users. In Pancasila classes, students can quickly use Moodle and all the features to increase their learning capacity. The feedback from students on Moodle was positive. They feel Moodle makes it easier for them to implement online learning in the early days. At this university, Pancasila learning is indeed studied by students who have just graduated from high school, so that lecturers often have their worries if students might find it difficult when learning using Moodle. In fact, in the initial three weeks, students gave positive responses with a high level of participation and response with high enthusiasm when participating in synchronous classes. The author suspects that M-Flex's application based on Moodle is a suitable pair of tools and materials and can encourage students' enthusiasm for learning during these times. 


\section{CONCLUSION}

This research showed the implementation of M-Flex based on Moodle is still experiencing several problems. Some negative feedback from students emerged due to internet access from their respective regions, which tended to be difficult and slow. Internet quota is expensive, even students cannot access Moodle offline. This is one of Moodle's weaknesses. Students cannot access Moodle if they are not connected to the internet, even though every learning resource, especially in Pancasila classes, can only be accessed through Moodle. Another obstacle felt by students, especially in the Pancasila class, is the lack of training in using Moodle. New generation students indeed dominate Pancasila class participants, they have just graduated from high school and are still new to the use of learning management systems like this Moodle. The lack of training in using Moodle made some students feel confused, and some became troublesome for lecturers with questions. M-Flex itself as a curriculum model applied by this university needs more improvement. Especially in designing assignments, like a forum, journal reading, mini paper, and other assignments. New students who took the Pancasila class, mostly have not been familiar with Moodle, activities, and also the assessment model that seems different when they were in high school.

\section{REFERENCES}

Amiroh. (2012). Membangun E-learning dengan Learning Management System Moodle. Jakarta: Genta Group Production.

Bork, A. (2012). Tutorial Distance Learning: Rebuilding Our Education System. Amsterdam: Springer Netherlands.

Bowo, A. (2016). Restaurant Choice for Indonesian Gen Y, Gen X and Baby Boomers. 2nd International Conference on Advanced Research in Business and Social Sciences 2016.

Brooks, M. D. (2019). Transforming Literacy Education for Long-Term English Learners: Recognizing Brilliance in the Undervalued. United Kingdom: Taylor \& Francis. 
Calle-Urgiléz, K. (2018). Virtual Learning Environment for Children with Disabilities: A Proposal Based on MOODLE and Content Management with Over The Top (OTT) Technology. 2018 International Conference on Electronics, Communications and Computers (CONIELECOMP).

Candarli, D. Y., \& Yuksel, H. G. (2012). Students' Perceptions of VideoConferencing in the Classrooms in Higher Education. Journal Social and Behavioral Sciences, 47(2012), 357-361. https://doi.org/10.1016/j.sbspro.2012.06.663.

Chatib, M., Hidayat, S., \& Siroj, R. A. (2019). Penerapan Pembelajaran Kooperatif Tipe Numbered Heads Together (NHT) Berbantuan Aplikasi Moodle untuk Meningkatkan Hasil Belajar Kognitif Peserta Didik di SMA Negeri Titian Teras Jambi. BIODIK, 5(1), 68-80. https://doi.org/10.22437/bio.v5i1.6393.

Dent, C. (2018). Moodle's Founder and CEO, Martin Dougiamas, Receives an Honorary Doctorate from Université Catholique de Louvain. Retrieved from Moodle: https://moodle.com/news/moodles-founder-ceo-martindougiamas-receives-honorary-doctorate-universite-catholique-de-louvain/. Accessed 9 August 2020.

Dvorak, R. (2011). Moodle for Dummies. Canada: Wiley.

Efriana, L. (2020). Problems of Online Learning during Covid-19 Pandemic in EFL Classroom and the Solution. JELITA: Journal of English Language Teaching and Literature, 2(1), 38-47.

Fashant, Z. (2019). Designing Effective Teaching and Significant Learning. Virginia: Sylus Publisher.

Fink, L. (2013). Creating Significant Learning Experiences: An Integrated Approach to Designing College Courses, Revised and Updated. San Francisco: Jossey-Bass.

Giorgi, B. (2020). Transition to Online Education in Schoolds during SARS-CoV2 Coronavirus (Covid19) Pandemic in Georgia. Pedagogical Research, $5(1), 1-8$. 
Edukasi: Jurnal Pendidikan, Volume 19 Nomor 2 Tahun 2021

Implementation of M-Flex Based Moodle in Pancasila Course.....

Juliana Tirza

Halaman 201-215

Kohkoc, M. (2019). Flexibility in e-Learning: Modelling its Relation to Behavioural Engagement and Academic Performance. Themes in Learning, 12(1), 1-16.

Meylani, R., Bitter, G., \& Legacy, J. (2015). Desirable Characteristics of an Ideal Online Learning Environment. Journal of Educational and Social Research, 5(1), 203-215. https://doi.org/10.5901/jesr.2015.v5n1p203.

Munir. (2012). Teknologi Informasi dan Komunikasi: Pembelajaran Jarak Jauh. Bandung: Alfabeta.

Mustafa, N. (2020). Impact of the 2019-20 Coronavirus Pandemic on Education. International Journal of Health Preferences Research, 4(1) 25-30.

Riyanto, L. D. (2011). Teknologi Informasi Pendidikan. Yogyakarta: Gava Media.

Rohana, R. (2019). Peningkatan Kemampuan Penalaran Matematis Mahasiswa Calon Guru melalui Pembelajaran Reflektif. Infinity Journal, 1(4), 105-119. https://doi.org/10.22460/infinity.v4i1.p105-119. 